\title{
The Lifeline for Suicide Prevention of Children and Teenagers in Bucharest, Romania
}

\author{
Emanuel Adrian Sârbua
}

\begin{abstract}
Suicide is one of the leading causes of teenagers' deaths. Even whether it is preventable, most of the time, there are still very few projects or actions of the local authorities and/or organisations in Romania, due to the lack of information and resources. The suicide prevention line for children and teenagers in Bucharest is presented and evaluated after five years of activity. It may be considered as one example of good practice, since it managed to put together local knowledge, human resources, and social actors. The suicide prevention line for children and teenagers in Bucharest has been established in 2009 by the General Directorate of Social Welfare of Bucharest Municipality, in partnership with the Psychiatric Hospital "Prof. dr. Alexandru Obregia". The finances are provided by the Welfare Department, the location belongs to the Psychiatric Hospital, and the mental health services are coordinated by a neuro-psychiatrist. There are about 30 volunteers taking the phone calls $24 / 7$. Since 2011, they established the Association of Suicidology.
\end{abstract}

\section{Keywords}

Suicide, prevention, lifeline, children, teenagers

It has been often speculated in the past decade, the fact that suicide has come to occupy one of three positions in the main causes of death among adolescents and young adults worldwide (Sarbu 2011; World Health Organization [WHO] 1999), respectively the 13th cause of death in all age groups (International Association for Suicide Prevention [IASP] 2008). Because, in the last half century, global suicide rate increased by $60 \%$ (Hellen 2007), numerous countries have introduced into their annual plans of action and strategies for medium- and long-term development, special policies to prevent the suicidal phenomenon. Moreover, if by the early 1990s, the majority of specialized work only exceptionally included information on depression in children and adolescents (Adams and Berzonsky 2009), despite the fact that its existence had been noticed since the early 1940 (Adams and Berzonsky 2009), today these subjects began to receive the deserved attention, for objective reasons.

Suicide is the second leading cause of death among adolescents and youth (15-24 years) in the US, and the percentage is twice as higher than in the 1970s (Adams and Berzonsky 2009). And at European level, things are somehow similar. According to Eurostat, Romania is the 13th country among European countries with the highest suicide rate in adolescents -for the age segment from 15th to 19th (Eurostat 2015) (see Figure 1).

\footnotetext{
aUniversity of Bucharest, Romania

Correspondent Author:

Emanuel Adrian Sârbu, Department of Baptist Theology, University of Bucharest, Berzei Street, No. 29, 1st District, Bucharest, Romania

E-mail: easarbu@gmail.com
} 


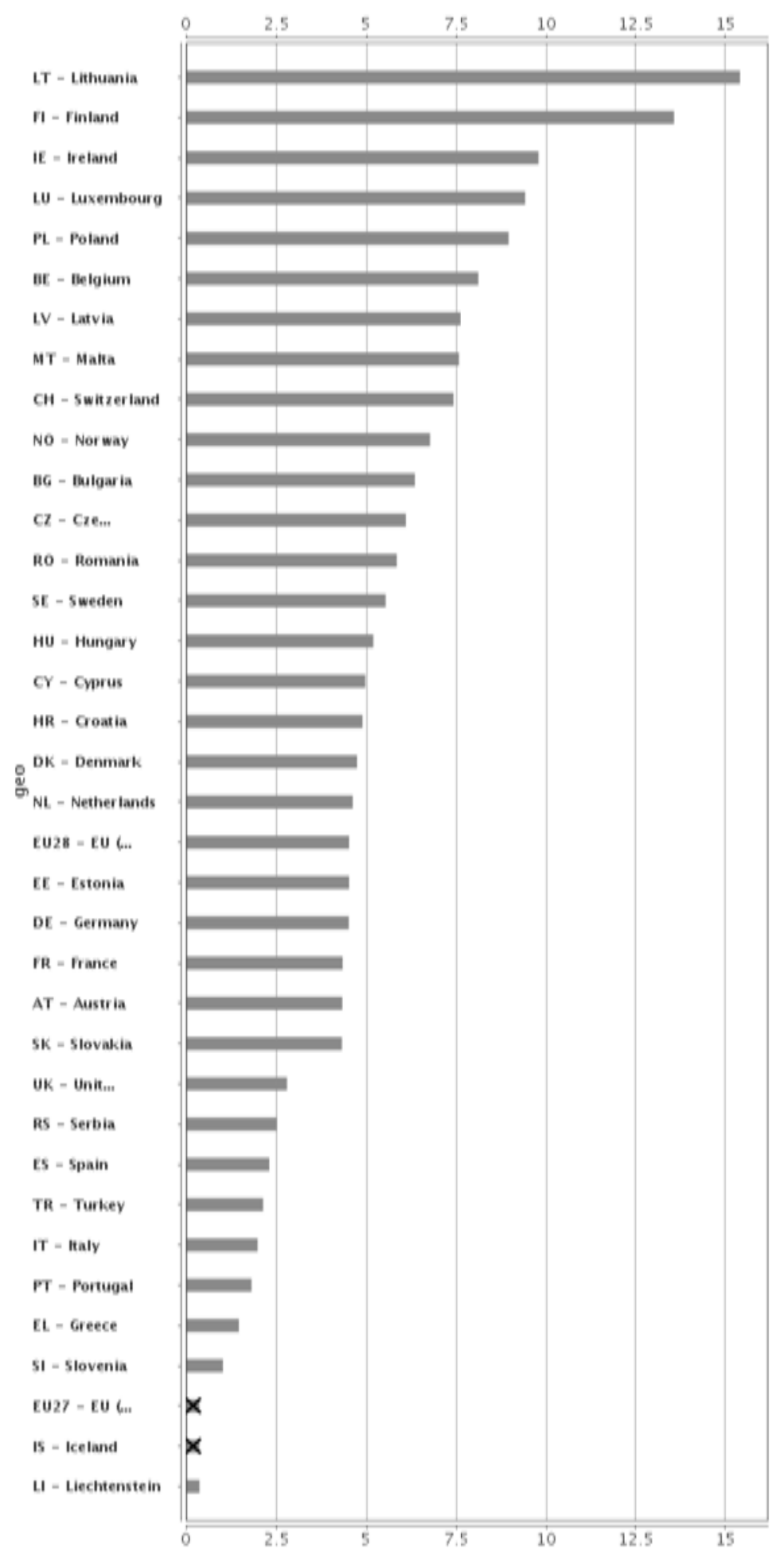

Exceptions: MT (2011)

Figure 1. Suicide Rates in the EU Countries [by Age Group (15-19)/100,000 Inhabitants]. Source: Eurostat $(2015)^{1}$. 
Unfortunately, as the population gets older, things are far from becoming better from this point of view. According to Eurostat, in the age segment 20-44 years, suicide represents $12 \%$ of all causes of mortality, almost as much as the rate of road accidents-13\%, and men are four times more numerous than women in this age cohort (Eurostat 2006).

In the European Union (EU), a new case of suicide is being recorded at every nine minutes, and the number of suicide attempts is estimated to be nine times higher. Annually, at the European level, are being reported approximately 59,000 suicide cases (Wahlbeck and Mäkinen 2008). A simple comparison with statistics of car accidents deaths - with approximately 50,000 deaths every year (Wahlbeck and Mäkinen 2008) - reveals that suicide is a particularly worrying phenomenon and that local authorities should take measures to prevent suicide attempts and to limit the phenomenon. This is why prevention activities in cases of depression and suicide are considered of priority in European Pact for Mental Health and Welfare (European Comission 2008) and in the report "Consensus Paper: Prevention of Depression and Suicide" (Wahlbeck and Mäkinen 2008), which recommends that member states should take firm, concrete, and immediate action.

In the European Pact for Mental Health and Welfare, member states are invited to set policy and act to prevent depression and suicide, taking into account aspects such as: training medical and social staff; restricting access to methods of potential suicide potential; taking practical steps for the awareness of the general public and professionals in the socio-medical sector and other relevant sectors; initiation of measures to reduce suicide risk factors such as excessive consumption of alcohol and/or drugs, social exclusion, depression, and stress; providing support mechanisms for people trying to commit suicide and their family members - and some of the cited examples are the telephone line services or internet portals offering emotional support.

The recommendations made by the Committee for the Rights of the Child (United Nations Organization 2009), which examined the third and the fourth periodic report of Romania, with the occasion of its meeting from June 12, 2009, stated that "The committee is concerned about suicides and violent behavior in children and adolescents, and the lack of prevention programs in this regard", recommending measures and policies to meet this problem and to contribute significantly to reducing them. Also, in the 68th paragraph, it can be found the following observation regarding the adolescent health: "Although it notes the efforts taken by the state party, the committee is concerned about media reports on suicides, especially among children left behind by parents working abroad, although no statistics are systematically drawn on this aspect".

\section{ESTABLISHING THE FIRST EMERGENCY LINE FOR PREVENTING THE SUICIDE IN BUCHAREST - THE NUMBER 0800.080.100}

In 2007, the city of Bucharest, through the General Directorate of Social Assistance of Bucharest, became part of ECAD (European Cities Against Drugs), and in 2008, performed the first research of the Youth in Europe Programme, considered to be the largest European program, promoting a healthy lifestyle addressed to adolescents (Sarbu, Bunaciu, and Maris 2014). Although the research did not directly targeted the adolescent suicidal ideation, the questionnaire also included a significant number of questions and variables about it, and also about issues like depression, wellbeing, bullying, the relational environment of the youth, their family environment, and other social issues. In the 2008 survey, 2,662 students from 46 high schools in Bucharest have been questioned. The results were rather alarming: $37.8 \%$ 
of the teens admitted that they knew people with suicide thoughts; $23.1 \%$ knew people or had friends who attempted to suicide; $19.2 \%$ had close friends who attempted suicide; $9.1 \%$ of them had acquaintances or people from their entourage who committed suicide; $5.8 \%$ had close friends or knew people who committed suicide; $15.8 \%$ of the respondents have thought to commit suicide themselves; $5.6 \%$ intended to commit suicide; $13.5 \%$ of respondents said they want to commit suicide; $5.6 \%$ of respondents had at least one attempted suicide; $2.4 \%$ of respondents had at least one attempted suicide in the school year 2008-2009.

Based on these results, in conjunction with the paradox that the adolescents from Bucharest seem to engage more in social relations with their online friends rather than with their regular entourage or with their parents (Sarbu et al. 2014), in 2009, it has been implemented a local initiative designed to meet their need to communicate in an empathic manner, to be heard and properly guided (Ciobanu 2005): A hotline has been set up, to offer them the possibility to call, free of charge, in order to be listened by a volunteer with an adequate, specialized training and in an environment of ensured anonymity.

Established by the Bucharest General Council Decision No. 308/2009 and entirely financed by the General Council of Bucharest Municipality, through the budget of the General Directorate of Social Assistance of Bucharest (according to HCGMB No. 308/2009 and HCGMB No. 13/2011), the hotline for children in Bucharest with self-destructive behavior is being operated by the Center for the Prevention of suicide attempts in children and adolescents, part of the "Prof. Dr. Alexandru Obregia" Psychiatric Hospital.

The highest costs of the project were recorded, as shown in Figure 2, in the first month of the project implementation, when the phone line was installed along with two workstations, and also when the telecommunication equipment has been bought; after this initial investment, the costs consist only from the monthly subscriptions for telephony services and monthly reports, totalizing an approximate amount of $\$ 300-\$ 360$.

In Figure 3, it can be seen that during the late fall and the winter season, the number of those seeking specialized care was considerably higher than in the summer (when the number of calls received was lower with about one third).

Compared with the rest of the months of project implementation, the major difference from November and December 2008 (with 2,300 calls in November and 1,564 calls in December), and even compared with the average of about 475 calls in the other "cold" months (by this term, we understand late autumn, the winter, and early spring, when it is said that the fatigue, the low temperatures, lack of sun and other so-called predisposing factors might also determine elevations in the dynamics of suicide, even whether there are no relevant studies in Romania to sustain this claiming), can be noticed a real boom that can only be explained by the constant and sustained media coverage during the project launch.

Also, analyzing the records of the volunteer operators who received the calls, it has been noticed a decrease in the number of the "false calls" (requests for general information, without reference to the activity of the hotline, people who call just to test the operability of service, callers who either hang up or refuse to dialogue about their suicidal ideation, etc.), which may indicate a certain selection of the hotline callers in favor of the ones who really need emotional support. Incidentally, the last item listed is supported by Figure 6 .

The trend of exponential growth comes back in July 2011 (when the number of calls tripled, reaching more than 900, from the average of 250 in the previous months). Starting with July 2011, a video spot promoting the hotline began to be broadcasted, free of charge, in the Bucharest public transportation vehicles (RATB-The Autonomous Transport 


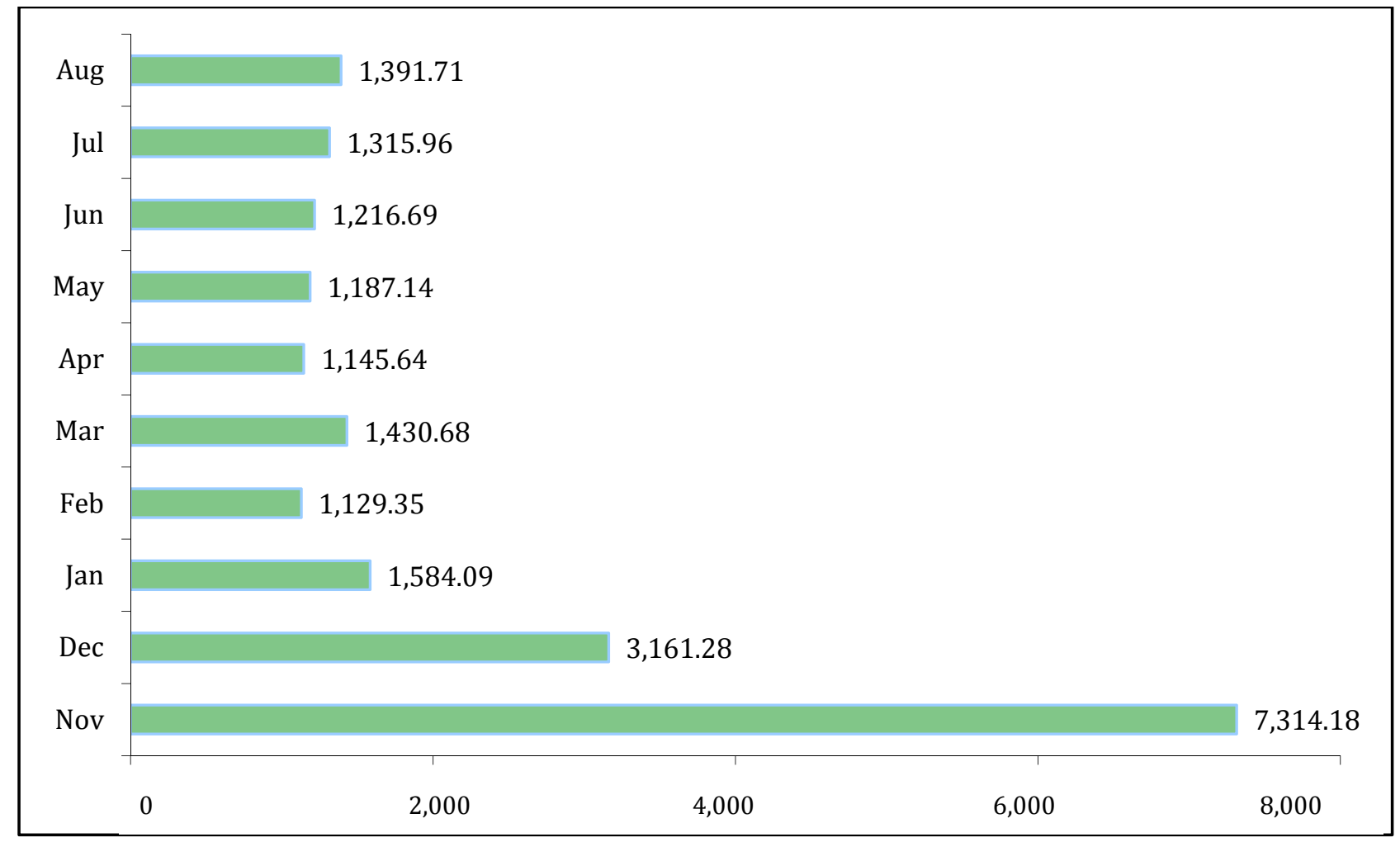

Figure 2. Hotline Costs (First Year of Implementation). Source: generated by the author.

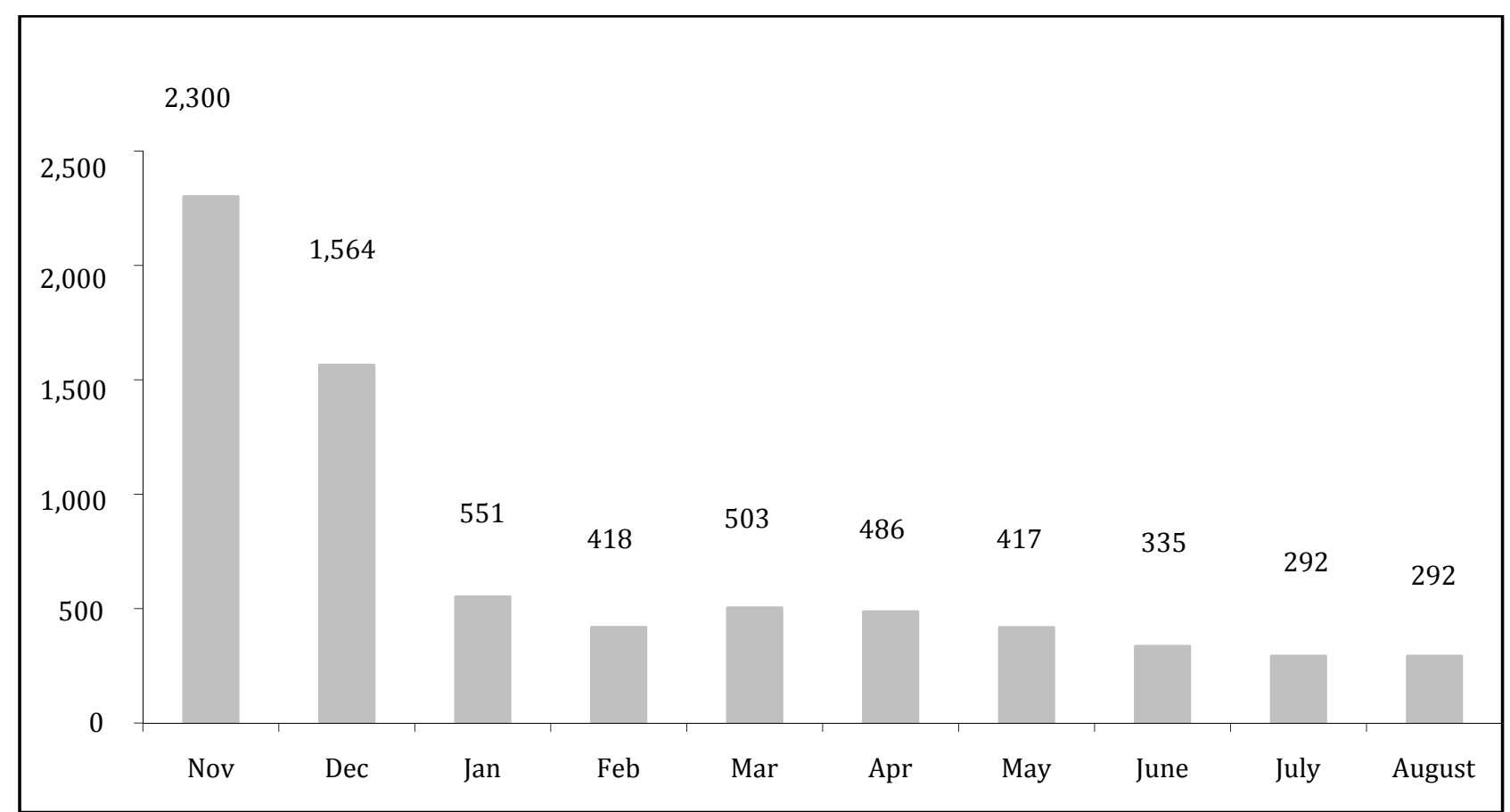

Figure 3. Number of Calls in the First Year of Implementation. Source: generated by the author. 
Administration Bucharest), at the initiative of the Suicidology Association ${ }^{2}$.

The fact that in the first two months of implementation of the project (November and December, 2009) has been registered a number of calls, almost similar to the entire year of $2010(3,864$ versus 4,037 ) can be explained, as mentioned before, by the innovative element brought by the hotline emotional support services in Romania, on one hand and, on the other hand, by a high number of "false calls". Since the first year of implementation (2010, two months after the beginning of 2009), it can be seen both in the statistics and in the operators' shift reports, a significant decrease of the "fake calls", which as stated, indicates a certain selection of the callers in the favor of the ones who really needed emotional support (see Figure 4).

Figure 5 also confirms the decreasing number of the "false calls", as it has been noticed by the voluntary operators of the lifeline. While in 2009, when it has been recorded a real explosion of calls to 0800.080.100, they discussed with the potential hotline beneficiaries 13,314 minutes, in 2010, the number of minutes was approximately $40 \%$ higher than the number in 2009, in spite of the fact that the number of calls for the entire year 2010 was very similar to that in November to December, 2009. The growing average of the amount of time spent in conversation, reported to the number of calls recorded (the trend is maintained in the coming years), confirms that the false calls have decreased exponentially.

In Figure 6, it can be noticed a significant number of received calls coming from mobile networks in the detriment of fixed networks and, on the other hand, a significant number of calls from those mobile network that at the moment, addressed themselves especially to the young people segment, offering them many minutes of conversation and text messages at reasonable price. Overall, most calls came (at least in the first two years), from the following networks: Orange, Cosmote, Vodafone, and Romtelecom. Dynamics suffered some changes in 2011 and 2012.

Regarding the dynamics of the phone calls to the lifeline, it can be said it has been influenced by either an increase, respectively by a significant decrease in the suicidal ideation among young people, which is unlikely to be thought and cannot be sustained or corroborated with relevant statistical data. Rather, it can be connected with the fact that, in certain period of times, the lifeline has been better promoted or, on the contrary, less effectively promoted, compared with the same period from the previous years. Another fact that must be kept in mind when analyzing this dynamic is that from 2012 to 2015 , there were actually two lifelines working together, in parallel-the number 0800.080.100 and the European 116.123. The transition period will end on September 10, 2015, when it will remain operational exclusively the European number for crisis intervention 116.123.

\section{ACCESSING THE EUROPEAN HOTLINE FOR COUNSELING IN CRISIS SITUATIONS-THE NUMBER 116.123}

With the occasion of the World Suicide Prevention Day celebrations (September 10) in 2011, the General Directorate of Social Assistance of Bucharest and the Psychiatric Hospital "Prof. Dr. Alexander Obregia" announced they accessed the national short number for harmonized social services 116.123 and that has been started a gradual replacement process of the green number (call free) 0800.080.100 with the new one. The national short numbers for harmonized social services like 116.123 have a pan-European identity, being used for the same services in all member states of the EU.

Given the so far achieved results, and given the opportunities to develop the helpline for children and adolescents in Bucharest with impending self-destructive 


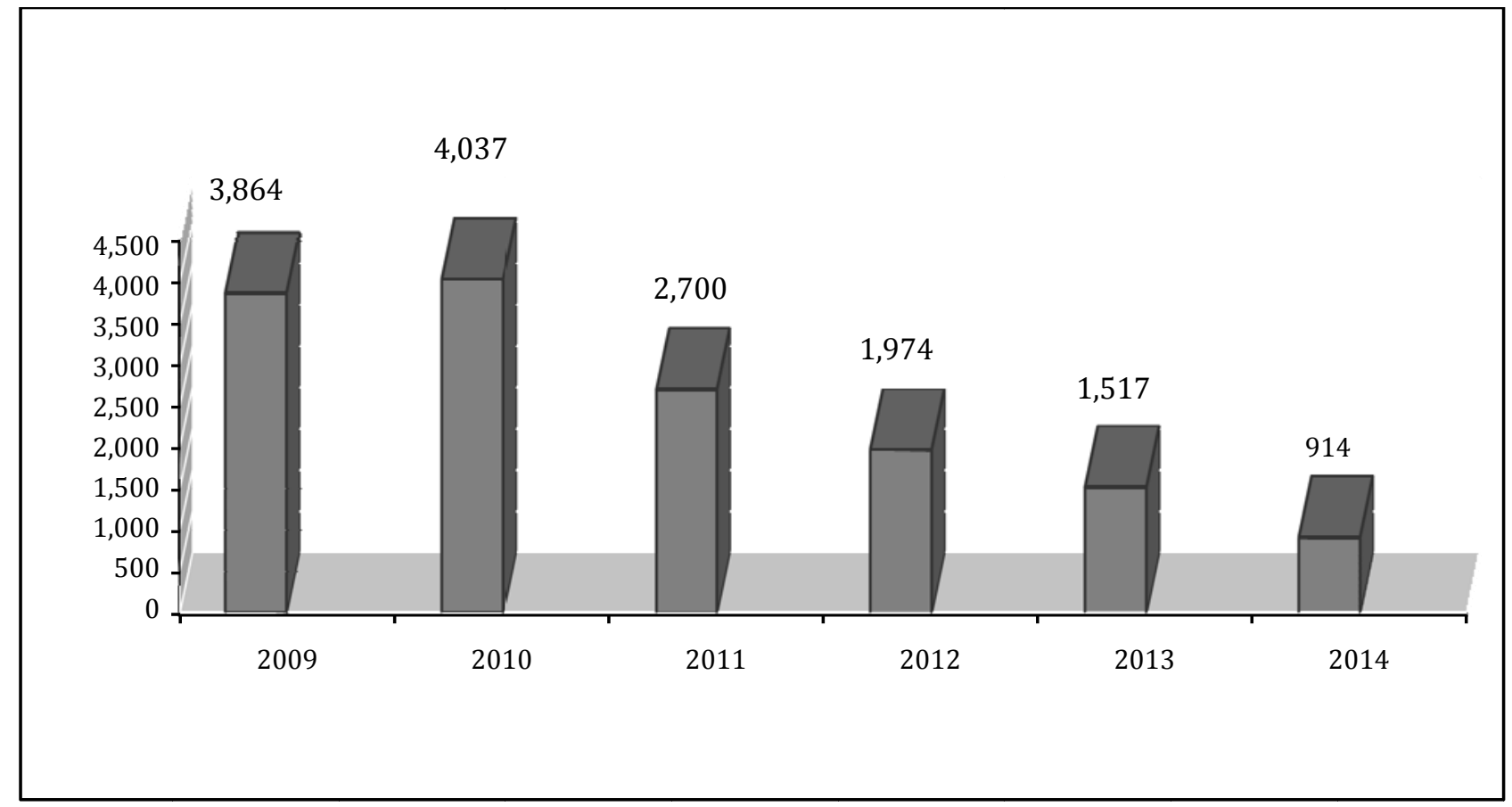

Figure 4. Total Calls per Year (November 2009-July 2013). Source: generated by the author ${ }^{3}$.

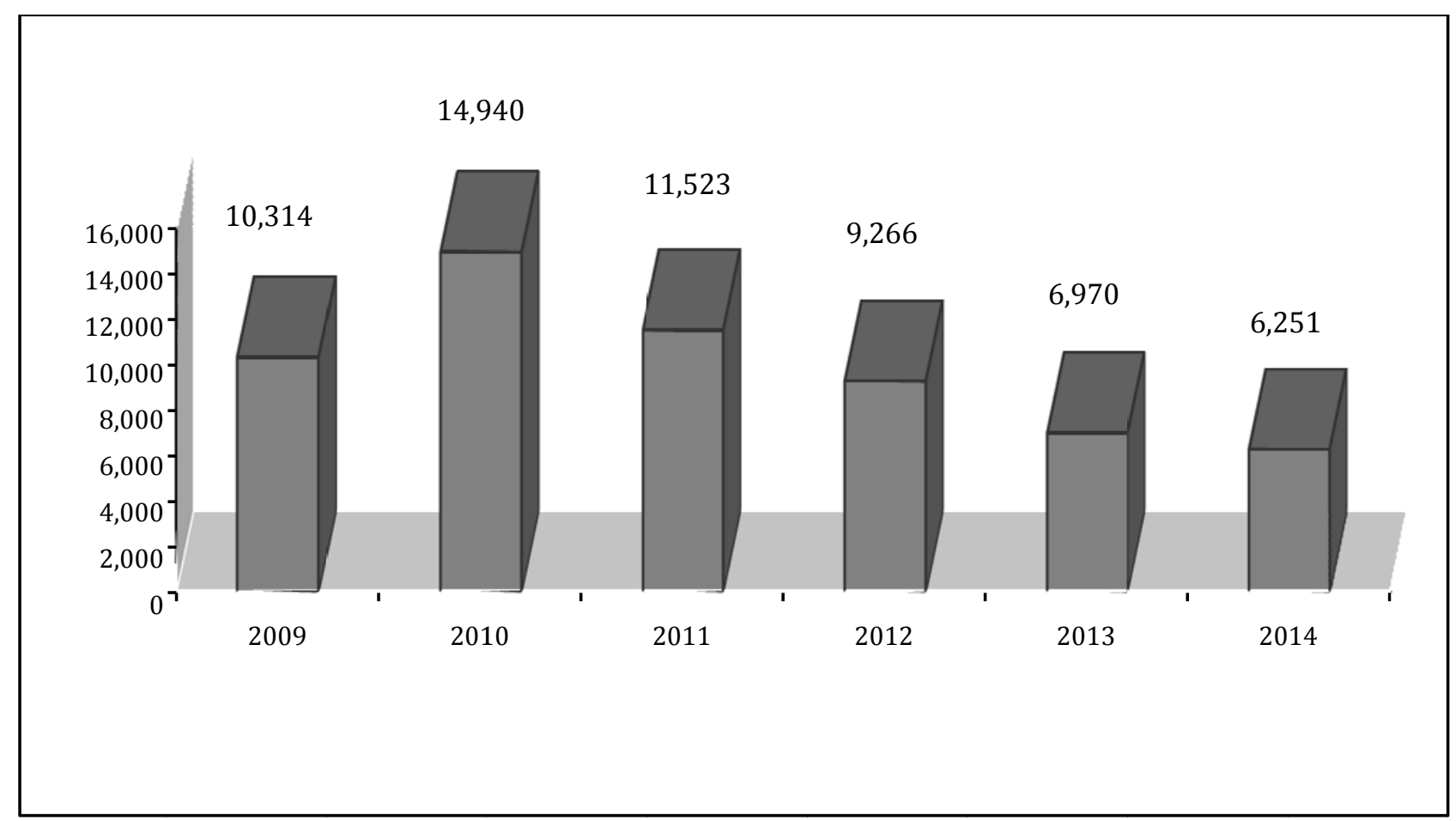

Figure 5. Total Minutes of Talk Time/Calendar Year (November 2009-July 2014). Source: generated by the author ${ }^{3}$. 


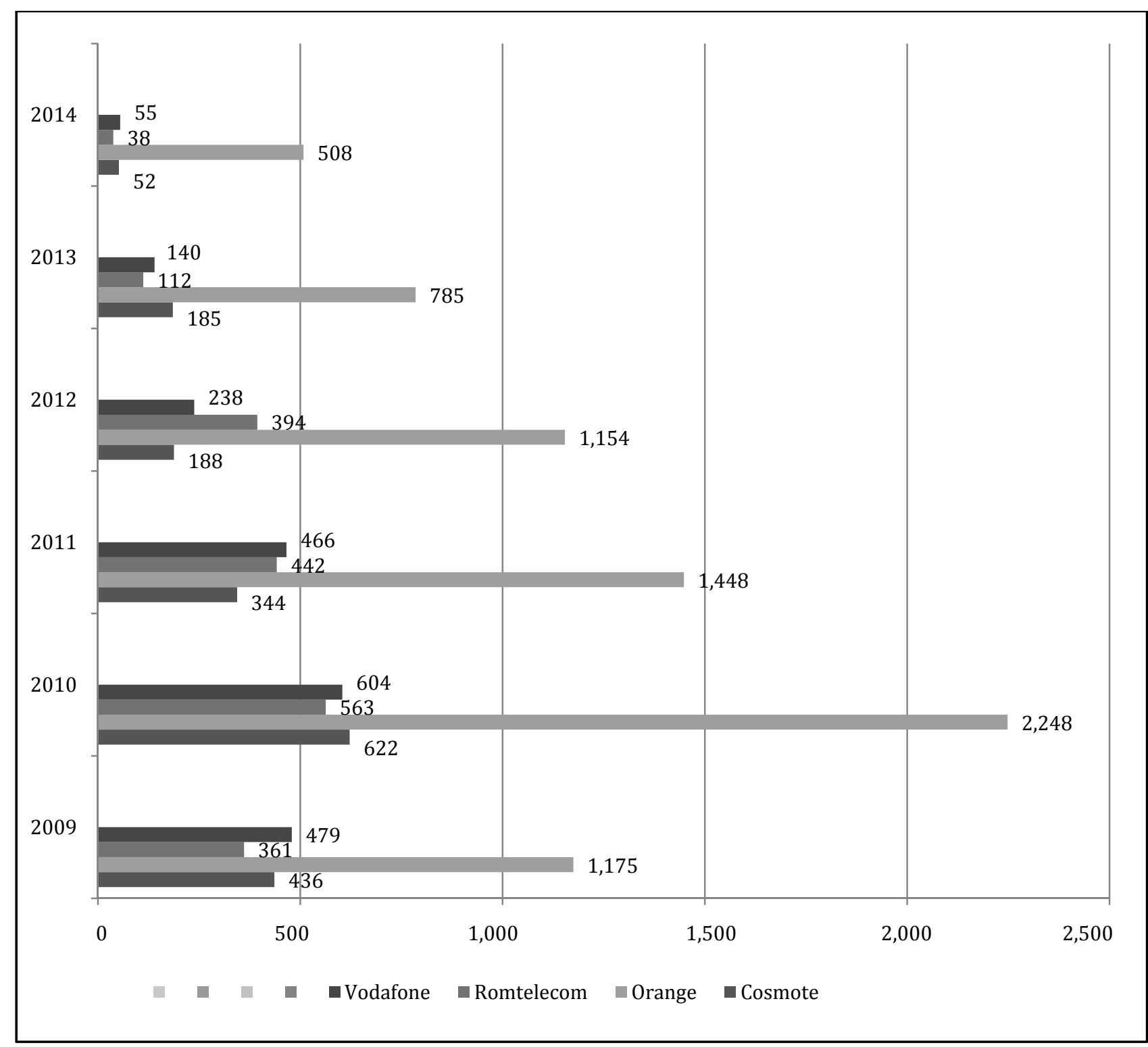

Figure 6. Total Calls in 2009-2014, on the Telephony Networks/Companies. Source: generated by the author.

conduct, which aims to provide specialized services for the youth with emotional crisis, available at distance, and also aiming to provide an easier to remember phone number for this target group, the previously mentioned institutions performed the necessary administrative steps to transform the 0800.080.100 in its upgraded version-116.123 (number provided by the Romanian National
Authority for Management and Regulation in Communications). Calls to the number 116.123 will remain free of charge (as they were in the case of 0800.080.100), and the pu blic access to these numbers was not in any way conditioned by a previous registration, identification, or recording the conversations.

It was initially decided that the green numbers will 
operate in parallel for a period of 90 days, taking into account the specificities of work and the need to ensure the continuity of the services offered to the beneficiaries, as well as to ensure a better information of the potential callers. However, since most of the calls continued to arrive on the number 0800.080 .100 , in conjunction with the lack of a considerable budget to promote the change and with the fact that the decision did not involved any additional costs, it has been decided to extend for an indefinite period the parallel operation of the two lifeline numbers, until will be noticed that the calls to 116.123 will prevail. In all of this period of time, the only promoted number will be 116.123 .

However, given the fact that the finances are provided by the General Council of Bucharest until November 1, 2015, following that the next period of time would make the object of a new decision of the deliberative public authority of the Romania's Capital city, corroborated with the fact that in all of this time, the old number 0800.080 .100 was not promoted at all, a symbolic date has been chosen for the completing of the transitional process: September 10, 2015, the International Day for Suicide Prevention.

\section{THE STRUCTURE OF THE CALLERS: SOCIO-DEMOGRAPHIC CHARACTERISTICS}

The age segment of the callers proved to be wider than it has been estimated in 2009, widening from 12 to 61 years. And this seems to be mainly a result of the fact that this approach is a national premiere, and also of the fact that there are no similar specialized services for the adult populationat a national level.

Regarding the calling motives claimed by the beneficiaries of the service, these may be grouped into nine major categories, in a strong connection with the following types of callers:

(1) Children from disorganized families: This category can be associated with problems caused by alcohol and drugs use of their parents, by the lack of communication between the family members, abuse, aggression and/or physical violence, verbal, emotional, and sexual exploitation of children by parents, etc.;

(2) Children left behind by parents working abroad. The analysis of the phone calls reports shows that most problems are associated with parental absence in their lives, in spite of the fact that they talk or communicate almost daily (through telephone or computer programs/applications like Skype, messenger, and Facebook), in conjunction with relationship difficulties with the ones that have been entrusted to take care of (grandparents, uncles, aunts, godparents, and neighbors). They are often accused of lack of affection and real concern for the problems the youth are facing; other issues here are the youth feeling of "belonging to no one", behavioral disturbances, and the lack of integration in the social/ peer group;

(3) Children who return home with their parents, and their parents go again to work abroad. It is a special category, with numerous social reintegration problems. Basically, they are midway between two different social and educational systems, making it extremely difficult to be able to fully fit in one of them. Thus, they feel perceived as being "different" by their peers, being somehow "foreigners in their own country";

(4) Teenagers and youth. Most of their problems are related to their emotional and/or family relationships of adolescents, in which have occurred either separation either other various unacceptable divergences. Also, in this category, it could also be placed the adolescents and the young people who have lost their friends and/or parents as a result of a decease, and they now have difficulties in managing or overcoming the grieving and mourning process;

(5) Parents, carers, friends, or acquaintances of the people in the target group of the project are making another distinct category, calling the helpline for children and adolescents in Bucharest. They require expert opinion or specialized help for (real, potential, 
or imaginary) problems that they identified in their children, relatives, or friends;

(6) People with various psychological, psychiatric, and/or medical illnesses. These persons can be grouped in people claiming suffering from conditions like anxiety, depression, schizophrenia, Alzheimer's, and various medical or physically conditions/illnesses, including patients in terminal stages of cancer, which may cause suicidal thoughts;

(7) Individuals with social integration difficulties. This category integrates a range of age groups and issues, from children who accuses integration difficulties in their school's community, to young people who have problems adapting to their job requirements or facing unemployment, and to adults or elderly with chronic illnesses or with special needs. Most of these problems can be reduced to their unfulfilled need to communicate with someone, that is being felt acutely and amplified until it reaches the point where a self-destructive behavior seems justifiable;

(8) Individual calling to express their gratitude for the emotional support offered by the centre's volunteer staff in a very difficult or delicate moment of the beneficiaries' lives;

(9) Test calls, from various people who watched the promotional materials and wanted to verify the functionality of the services.

\section{CALL MANAGEMENT BY THE VOLUNTEER STAFF}

Since the telephone service was established as a result of becoming aware of a real emotional need of a certain segment of the resident population in Bucharest area, corroborated with the fact that this was happening in a time of a significant financial crisis, it has been decided to make a full use of the currently existing resources. So the hotline operates without permanent employees, the active listening services being provided voluntarily by employees of partner institutions and by other volunteers who have a minimal training in communication area.

At the moment, the telephone services are provided on a $24 / 7$ base by about 30 volunteers - students (BA, Master, and PhD students) and/or graduates of higher education institutions or post-secondary from the following (but not exclusively) fields: healthcare/medicine, psychiatry, psychology, sociology, theology, social work, etc. A medical doctor, neuro-psychiatrist and doctor in medical sciences coordinate their voluntary activity. All the volunteers must first sign a written agreement with the "Prof. Dr. Alexander Obregia" Psychiatric Hospital,where lifeline is operated.

Each potential volunteer is admitted to the center after their Curriculum Vitae (CVs) and documents certifying their training in the areas mentioned earlier, as well as a letter of intention/motivationare being analyzed. Once this stage is completed, it is followed by the interview, in which they are being evaluated by the volunteer's coordinator. Each candidate undertakes the obligation to respect the rules and the ethical code of the center and of their specific profession/formation, and, where applicable, the ethical codes from the fields of social welfare and psychology/counseling. The admitted candidates will have at least a minimum theoretical training (in which are being introduced to the principles of the empathic and active listening, warning signs of imminent self-destructive behavior, etc.) and a practical training, in which they assist to the answering calls activities, together with experienced volunteers.

It is important to mention that the technology used in the suicide prevention helpline for children and adolescents in Bucharest allows that in the situations that individual volunteers cannot manage by themselves, the call can be forwarded either to the coordinator or to another volunteer that is more experienced, or, where appropriate, they can consult with others for the optimal management of the encountered casuistry. 
The protocol states that, when the volunteers answering the calls do notice there is (or might be) an imminent suicidal risk for the callers, the volunteer will expose to the caller his/ her belief (clearly and firmly stated) that they need to dial 112-the European Emergency Service, in order to receive an adequate and rapid intervention for their situation; the callers are encouraged to do that or they have the possibility to allow the volunteer to do it, as far as the caller provides information about its current position (either on its own initiative or at the request of the volunteer in the service at the moment), and the case will be sent with the utmost celerity to the emergency services. Given the impossibility of locating the calls from users with prepaid telephone services, if they refuse either to call themselves to 112 or to provide to the hotline volunteers the necessary information that will allow forwarding the case to the emergency services, the conversation must end, in order to give them the opportunity to call for help later.

\section{CONCLUSIONS}

The need of such a telephone service in Romania's cultural context is obvious. Equally obvious is, in our perspective, the activity broadening from Bucharest to the national level, and from children and adolescents to the general population (existing enough signals in the analysis of the calls and from the callers for the fact that there are many requests from all over the country and from all age groups, not just from minors). But such a development, even though it is naturally, cannot be done without the professionalization of the service and without strengthening the response capacity of the volunteers. And this can be practically translated into a number of elements that includes at least the following:

(1) Developing the capacity of the human resource in order to manage the phone calls, by expanding the network of volunteers, so there will no longer exist work shifts that are "uncovered", or "covered" by a single volunteer. Given the fact that currently, one shift lasts for four hours per volunteer, a simple calculation shows that, if each volunteer would have to complete only four shifts per month (or one shift per week), the hotline would require minimum 100 volunteers. Developing the capacity of the human resource also involves an increased attention paid to the training of the volunteers, to monitoring their answering activity (and shift reports), and to increasing the capacity to manage the encountered individually situations by the taken casuistry;

(2) Developing procedures for each operation and possible situation, which the volunteers will be aware of, will assume and follow; those procedures need to be clear, easy to understand and to apply;

(3) The implementation and/or adaptation of some good models practice, encountered in institutions or organizations which manage similar initiatives, in countries with longer experience, and also joining a federative/associative structure (e.g., Befrienders Worldwide International, Samaritans, etc.), in order to benefit from their expertise in training and organizational development, and also in the way that services are being provided;

(4) Giving greater attention to issues like advertising the telephone number 116.123, by including the necessary amounts of money in the budget and/or by exploring the legal possibilities for getting the free broadcasting on the radio/TV;

(5) Analyzing the possibilities of signing partnership agreements with other similar initiatives from the local levels, as well as with the national emergency services, and establishing the rules and procedures that should be applied in extreme situations. Also, if the extension of the service at the national level will be taken into consideration, then it could be taken into account the opportunity to cooperate with the Romanian organizations and institutions that have developed similar services for their local areas or in a limited time-frame (from the cities of Cluj, Iasi, etc.). For example, if the possibility 
of calls transferring is being agreed by all the involved partners, each one of these organizations/institutions could take all the call in a certain time-frame that has been decided together, so that their volunteers could suspend their activities in the other hours that will be covered by partners from another city; in the same time, by taking such a decision, the overall capacity to respond in emergencies is being strengthened, the overload (exhaustion) and the voluntary human resources fluctuation will be avoided.

Finally, taking into account only the local background and resources (in Bucharest, Romania), the development perspectives of the presented social service may include providing additional services like psychological counseling, psychiatric consultation, support groups, so that the beneficiaries with medical insurance and also the uninsured ones could have access to these kinds of services, through the Association of Suicidology, with the support of the two institutions under the authority of the General Council of Bucharest Municipality.

\section{Funding}

This work received financial support through the "Young Successful Researchers-Professional Development in Interdisciplinary and International Context": POSDRU/159/1.5/S/132400, financed by the European Social Fund through the Operational Programme Human Resources Development 2007-2013.

\section{Notes}

1. The chart is drawn based on the reports from member countries, being selected only the 15-19 age group. It should be mentioned the fact that there may be significant differences in the ways of recording and the reporting of suicides in the different member states.

2. Suicidology Association is a Romanian NGO (non-governmental organization) founded in 2011 by the volunteers of Center for Prevention of Suicide Attempts in children and adolescents, as well as by specialists in various fields involved in suicide prevention issues-psychiatry, neurology, psychology, sociology, theology, social welfare, etc.
3. For 2009, the paper refers only to the last two months of the year, from November to December, when the service came into existence.

\section{References}

Adams, G. and M. Berzonsky. 2009. Psihologia adolescenței. Manualul Blackwell (The Psychologyof Adolescence. The Blackwell Handbook). Iaşi: Polirom.

Ciobanu, M. 2005. Sănătatea optimă de-a lungul vieții. Adolescenții (The Optimal Healh Throughout Life. The Teenagers). Suceava: Accent Print.

European Commission. 2008. Pactul European pentru Sănătate Mintală şi Bunăstare. Conferință la înalt nivel a Uniunii Europene "Împreună pentru sănătate mintală şi bunăstare" (The European Pact for Mental Health and Wellbeing. The European Union Summit Together for Mental Health and Wellbeing). Bruxelles: European Comission. Retrieved (http://ec.europa.eu/health/mental_ health/docs/mhpact_ro.pdf).

Eurostat. 2006. "Causes of Death in the EU 25." Eurostat News Release, 26. Retrieved (http://ec.europa.eu/eurostat/ documents/2995521/5249938/3-18072006-AP-EN.PDF/02e d0244-0b72-4dd7-90af-923427970fdd?version=1.0).

_ 2015. Rata sinuciderilor în țările UE, pe grupe de vârstă (15-19 ani)/100.000 de locuitori [Suicide Rates in the EU Countries, by Age Group (15-19) 100,000 Inhabitants]. Retrieved (http://ec.europa.eu/eurostat/tgm/ graph.do?tab=graph\&plugin=1\&pcode=tsdph240\&languag $\mathrm{e}=$ en\&toolbox $=$ sort).

Helen, M. 2007. Despre sinucidere (About Suicide). Filipeştii de Târg, Prahova: Antet XX Press.

International Association for Suicide Prevention (IASP). 2008. Think Globally. Extent of the Problem. International Association for Suicide Prevention. Retrieved (http://www.iasp.info/wspd/2008_wspd_index.php\#thinkgl obally-extentproblem).

Sârbu, E. A. 2011. Suicidologie integrativă (Integrative Suicidology). Bucureşti: Ars Academica.

Sârbu, E. A., O. I. Bunaciu, and D. Mariş. 2014. The Substance Use and Social Factors in Bucharest 2012-2013. Cluj-Napoca: Risoprint.

The General Council of Bucharest Municipality. 2009. Hotărârea Consiliului General al Municipiului Bucureşti nr. 308/2009 privind aprobarea acordului de asociere între Direcția Generală de Asistență Socială a Municipiului Bucureşti şi Spitalul "Prof. Dr. Alexandru Obregia" în vederea derulării proiectului "Centrul de prevenire a tentativelor de suicid la copii si adolescent" (The Decision of Bucharest General Council No. 308/2009 Regarding the Approval of the Partnership Agreement Between the 
General Directorate of Social Assistance of Bucharest Municipality and the Psycyatric Hospital "Prof. Dr. Alexandru Obregia" to Implement Together the Project "The Suicide Attempts Prevention Centre for Children and Adolescents"). Bucharest: The General Council of Bucharest Municipality.

_. 2011. Hotărârea Consiliului General al Municipiului Bucureşti nr. 13/2011 privind actul adițional la acordul de asociere între Direcția Generală de Asistență Socială a Municipiului Bucureşti şi Spitalul "Prof. Dr. Alexandru Obregia" în vederea derulării proiectului "Centrul de prevenire a tentativelor de suicid la copii şi adolescenți" (The Decision of Bucharest General Council No.13/2011 Regarding the Additional Act to the Partnership Agreement Between the General Directorate of Social Assistance of Bucharest Municipality and the Psycyatric Hospital "Prof. Dr. Alexandru Obregia" to Implement Together the Project "The Suicide Attempts Prevention Centre for Children and Adolescents"). Bucharest: The General Council of Bucharest Municipality.

United Nations Organization. 2009. România şi Convenția cu privire la drepturile copilului. Recomandările Comitetului ONU pentru Drepturile Copilului 2009 (Romania and the Convention on the Children's Rights. The Recommendations of the UN Committee on the Children's
Rights 2009). Retrieved (http://www.salvaticopiii.ro/ upload/p000200000002_Recomand\%C4\%83rile\%20Comit etului $\% 20$ ONU\%20pentru $\% 20$ Drepturile $\% 20$ Copilului $\% 20$ 2009.pdf).

Wahlbeck, K. and M. Mäkinen, eds. 2008. "Prevention of Depression and Suicide." Consensus Paper. Luxembourg: European Communities.

World Health Organization (WHO). 1999. Country Reports and Charts Available. Introduction (adapted from: World Health Organization. Figures and Facts About Suicide). Geneva: WHO. Retrieved (http://www.who.int/mental_ health/prevention/suicide/country_reports/en/index.html).

\section{Bio}

Emanuel Adrian Sârbu, Ph.D., seniour lecturer, Department of Baptist Theology (Theology and Social Work), University of Bucharest; Head of Department for the Relation with the Civil Society and other Social Actors, the General Directorate for Social Welfare of Bucharest Municipality; founder member and research director, Association of Suicidology; research fields: suicidology, sociology, social research, social policies, and theology. 